\title{
KEEFEKTIFAN PEMBELAJARAN MATEMATIKA REALISTIK PADA SISWA KELAS VII SMP NEGERI 18 MAKASSAR
}

\author{
Taufiq \\ ${ }^{1}$ Universitas Cokroaminoto Palopo, Jl. Latammacelling No.19, dan Palopo \\ Uphy858@gmail.com
}

\begin{abstract}
Abstrak
Penelitian ini adalah penelitian eksprimen dengan menggunakan satu kelas sebagai kelas uji coba yaitu kelas $\mathrm{VII}_{5}$ dengan jumlah siswa 34 orang. Penelitian ini bertujuan untuk mengetahui keefektifan pendekatan Pembelajaran Matematika Realistik pada siswa kelas VII SMP Negeri 18 Makassar dengan mengacu pada 3 kriteria keefektifan pembelajaran yaitu tercapainya ketuntasan secara klasikal, aktifitas siswa berada pada rentang waktu ideal, dan diatas $80 \%$ siswa menunjukkan respon positif terhadap pelaksanaan pembelajaran matematika realistik. Penelitian dilaksanakan selama 5 kali pertemuan. Teknik pengumpulan data yang digunakan adalah tes hasil belajar yang diberikan kepada siswa pada akhir pokok bahasan, lembar observasi untuk mengamati aktivitas siswa selama proses pembelajaran berlangsung, dan angket respons siswa untuk mengetahui tanggapan dan saran siswa terhadap pelaksanaan pembelajaran matematika realistik. Hasil uji coba menunjukaan bahwa : (1) skor rata-rata tes hasil belajar siswa adalah 45,85 dan berada pada kategori rendah dengan standar deviasi 19,43 dimana skor terendah yang diperoleh adalah 10,00 dan skor tertinggi adalah 85,00 dari skor ideal 100. Dari hasil tersebut diperoleh bahwa 9 siswa atau $26,47 \%$ mencapai ketuntasan individu dan ini berarti bahwa ketuntasan secara klasikal tidak tercapai. Hal ini disebabkan kemampuan siswa dalam menyelesaikan masalah kontekstual masih kurang, kemampuan guru masih kurang, pembelajaran matematika realistik merupakan hal baru dalam pembelajaran matematika di SMP Negeri 18 Makassar.(2) semua kategori aktivitas siswa berada pada rentang waktu ideal. (3) angket respons siswa menunjukkan $85,03 \%$ siswa memberikan respon positif terhadap pelaksanaan pembelajaran matematika realistik. Berdasarkan hasil uji coba maka pembelajaran

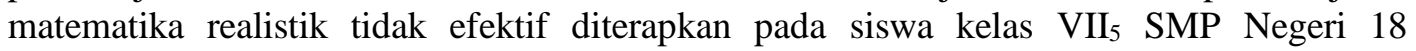
Makassar.
\end{abstract}

Kata Kunci: Keefektifan, Realistik.

\begin{abstract}
This research is an experiment research by using one class as try out class, it is $\mathrm{VII}_{5}$ class with 36 students. Purpose of this research is to find out the effectiveness of Realistic Mathematics Learning approach for students of VII class, State Junior High School of 18 Makassar, by refer to the three criteria of a learning effectiveness, they are classical thoroughness, students' activity is in ideal period, and more than $80 \%$ students' with positive response. This research consist of 5 time meeting. The data are collected by giving learning result test for the student' at last meeting of the current topic, using observation sheet to observe the students' activity during the learning period, and students' response questionnaire to find out the students' response and suggestion about realistic mathematics learning. The collected data show that : (1) The mean score of learning result test is 60.76 , it is in medium category, with standard of deviation 27.75, the lowest score is 21 and the highest score is 97 from ideal score of 100 . Those data show that 21 students' or $61.76 \%$ achieve the individual thoroughness and it is mean that classical thoroughness is not achieved. (2) All of students' activities category is in ideal period. (3) students' response questionnaire show that $85.03 \%$ of students' show positive response for the implementation
\end{abstract}


of realistic mathematics learning. According to the try out test, realistic Mathematics learning is not effective for the students of VII 5 class, State Junior High School of 18 Makassar.

Keywords: The effectiveness, Realistic.

\section{Pendahuluan}

Di dalam bidang pendidikan masih dirasakan adanya permasalahan yang belum seluruhnya dapat terpecahkan. Bermula dari perencanaan, penyelenggaraan, begitu pula hasil yang dicapai belum sepenuhnya memenuhi harapan.

Berkaitan dengan proses pembelajaran, paradigma mengajar di Indonesia mempunyai ciri-ciri antara lain guru lebih banyak mendominasi proses pembelajaran, pemahaman peserta didik cenderung bersifat instrumental, peserta didik hanya diam secara fisik dan kurang konsentrasi memperhatikan apa yang diajarkan oleh guru. Proses yang terjadi tidak selalu diarahkan untuk membentuk manusia yang cerdas, memiliki kemampuan memecahkan masalah, serta kurang diarahkan untuk membentuk manusia yang kreatif dan inovatif.

Sutarto Hadi mengemukakan bahwa guru matematika idealnya harus mengambil peran sebagai mediator, yaitu tidak hanya "menyuapkan" informasi kepada siswa-siswanya, tetapi memberikan kesempatan untuk membangun dan bertukar pikiran. Sebagai seorang mediator, guru menempatkan ide-ide siswa ke dalam konteks pelajaran, menghubungkan pemikiranpemikiran yang muncul satu dengan lainnya, dan membantu siswa memformulasikan dan merealisasikan ide-ide mereka. Oleh karena itu, untuk mencapai penguasaan pelajaran, orientasi pendidikan perlu diubah, di mana dalam evaluasi atau pengujian secara simultan harus ada keseimbangan antara "soal-soal hitungan" dan "soal-soal berpikir". Demikian disampaikan oleh Profesor Dr. Christa Kaune dari Osnabrueck University, Jerman. Kaune diundang sebagai pembicara tamu pada Seminar Nasional Pendidikan Matematika di Universitas Sanata Dharma pada 6 dan 7 Oktober 2006.

Prof Dr. Zulkardi menjelaskan tentang peran soal kontekstual dalam pembelajaran matematika. Menurutnya, pembelajaran matematika akan lebih bermakna dan menarik bagi siswa jika guru menghadirkan masalah-masalah kontekstual dan realistik, yaitu masalahmasalah yang sudah dikenal, dekat dengan kehidupan riil sehari-hari siswa. Masalah konstekstual dapat digunakan sebagai titik awal pembelajaran matematika dalam membantu siswa mengembangkan pengertian terhadap konsep matematika yang dipelajari dan juga bisa digunakan sebagai sumber aplikasi matematika. Masalah kontekstual dapat digali dari (1) Situasi personal siswa; situasi yang berkenaan dengan kehidupan sehari-hari siswa, baik di rumah dengan keluarga, dengan teman sepermainan, dan sebagainya. (2) Situasi sekolah/akademik; situasi yang berkaitan dengan kehidupan akademik di sekolah dan kegiatankegiatan yang berkaitan dengan proses pembelajaran. (3) Situasi masyarakat; situasi yang terkait dengan kehidupan dan aktivitas masyarakat sekitar siswa tinggal. (4) Situasi saintifik/matematika; situasi yang berkaitan dengan fenomena substansi secara saintifik atau berkaitan dengan matematika itu sendiri.(Sutarto Hadi)

Demikian juga pada SMP Negeri 18 Makassar, guru lebih banyak mendominasi proses pembelajaran. Karakteristik siswa kelas VII SMP Negeri 18 Makassar sangatlah bervariasi, ada siswa yang sangat antusias belajar tapi kemampuannya dalam matematika masih kurang, ada juga siswa yang bisa dikatakan memiliki kemampuan tinggi dalam matematika tapi dia tidak antusias dalam mengikuti pembelajaran matematika.

Teori Pembelajaran Matematika Realistik atau yang biasa disingkat dengan PMR sejalan dengan teori belajar yang berkembang saat ini, seperti konstruktivisme dan pembelajaran kontekstual (Cotextual Teaching and Learning, disingkat CTL) . Tetapi, 
pendekatan konstruktivis dan CTL mewakili teori pembelajaran secara umum, berbeda dengan PMR yang dikembangkan khusus untuk pembelajaran matematika.

Konsep PMR sejalan dengan kebutuhan untuk memperbaiki pendidikan matematika di Indonesia yang didominasi oleh persoalan bagaimana meningkatkan pemahaman siswa tentang matematika dan mengembangkan daya nalar mereka. Salah satu pertimbangan mengapa Kurikulum 1994 direvisi adalah banyaknya kritik yang mengatakan bahwa materi pelajaran matematika kurang relevan dan kurang bermakna (Kurikulum 1994 Akhirnya Disempurnakan, 1999).

Pembelajaran Matematika Realistik menggabungkan pandangan tentang apa itu matematika, bagaimana siswa belajar matematika, dan bagaimana matematika harus diajarkan. Freudenthal berkeyakinan bahwa siswa tidak boleh dipandang sebagai passive receivers of ready-made mathematics (penerima pasif matematika yang sudah jadi). Menurutnya pendidikan harus mengarahkan siswa kepada penggunaan berbagai situasi dan kesempatan untuk menemukan kembali matematika dengan cara mereka sendiri. Banyak soal yang dapat diangkat dari berbagai situasi (konteks), yang dirasakan bermakna sehingga menjadi sumber belajar. Konsep matematika muncul dari proses matematisasi, yaitu dimulai dari penyelesaian yang berkait dengan konteks (context-link solution), siswa secara perlahan mengembangkan alat dan pemahaman matematik ke tingkat yang lebih formal. Model model yang muncul dari aktivitas siswa dapat mendorong terjadinya interaksi di kelas, sehingga mengarah pada level berpikir matematik yang lebih tinggi.

\section{Metode Penelitian}

Jenis penelitian ini adalah penelitian eksprimen yang melibatkan satu kelas sebagai kelas eksprimen atau kelas uji coba dengan tujuan untuk mengetahui keefektifan pembelajaran matematika realistik pada siswa kelas VII SMP Negeri 18 Makassar.Desain penelitian ini adalah One Shot Case Study, yaitu sebuah eksprimen yang dilaksanakan tanpa adanya kelompok pembanding dan juga tanpa tes awal.

Penelitian ini dilaksanakan di SMP Negeri 18 Makassar. Populasi dari penelitian ini adalah seluruh siswa kelas VII SMP Negeri 18 Makassar yang terdiri dari 6 kelas dengan banyak siswa setiap kelas kurang lebih 35 orang. Pembelajaran matematika realistik belum tersosialisasi pada pendidikan sekolah menengah sehingga penulis memilih kelas VII sebagai awal dari sosialisasi pembelajaran matematika realistik pada pendidikan sekolah menengah. Sampel dalam penelitian ini adalah seluruh siswa kelas VII 5 SMP Negeri 18 Makassar. Pengambilan sampel dalam penelitian ini dilakukan dengan menggunakan teknik penyampelan random sampling.

Prosedur pelaksanaan penelitian dimulai dengan tahap persiapan, tahap pelaksanaan dan tahap analisis. Instrument penelitian yang digunakan adalah tes hasil belajar, lembar observasi aktivitas siswa dan angket respons siswa.

\section{Hasil dan Pembahasan}

1. Hasil belajar siswa

Data hasil belajar siswa setelah pembelajaran matematika realistik pada siswa kelas VII5 SMP Negeri 18 Makassar,selanjutnya dianalisis dengan menggunakan analisis statistik deskriptif yang hasilnya dapat dilihat pada tabel 4.1 berikut :

Tabel 4.1 Statistik Skor Hasil Belajar Matematika Siswa Kelas VII 5 SMP Negeri 18 Makassar.

\begin{tabular}{lll}
\hline No & Statistik & Nilai \\
\hline
\end{tabular}




\begin{tabular}{lcc}
\hline 1 & Skor ideal & 100,00 \\
2 & Skor terendah & 10,00 \\
3 & Skor tertinggi & 85,00 \\
4 & Rentang skor & 75,00 \\
5 & Rata-rata skor & 45,85 \\
6 & Standar deviasi & 19,43 \\
\hline
\end{tabular}

Pada tabel 4.1 dapat dilihat bahwa skor rata-rata hasil belajar siswa Kelas $\mathrm{VII}_{5} \mathrm{SMP}$ Negeri 18 Makassar setelah dilakukan proses belajar mengajar dengan menggunakan pendekatan pembelajaran matematika realistik adalah 45,85 dari skor ideal 100 yang mungkin dicapai oleh siswa, dengan standar deviasi 19,43. Skor yang dicapai oleh siswa tersebar dari skor terendah 10,00 sampai dengan skor tertinggi 85,00 dengan rentang skor 75,00.Jika hasil belajar matematika siswa dikelompokkan kedalam 5 kategori maka diperoleh distribusi frekuensi dan persentase sebagai berikut:

Tabel 4.2 Distribusi Frekuensi dan Persentasi Skor Hasil Belajar Matematika Siswa Kelas VIII 2 SMP Negeri 23 Makassar

\begin{tabular}{|c|c|c|c|c|}
\hline No. & Skor & Kategori & Frekuensi & Persentase \\
\hline 1 & $0-34$ & Sangat rendah & 10 & $29,41 \%$ \\
\hline 2 & $35-54$ & Rendah & 14 & $41,18 \%$ \\
\hline 3 & $55-64$ & Sedang & 4 & $11,76 \%$ \\
\hline 4 & $65-84$ & Tinggi & 5 & $14,71 \%$ \\
\hline 5 & $85-100$ & Sangat tinggi & 1 & $2,94 \%$ \\
\hline \multicolumn{3}{|c|}{ Jumlah } & 34 & $100 \%$ \\
\hline
\end{tabular}

Pada tabel 4.2 diatas menunjukkan bahwa dari 34 siswa kelas $\mathrm{VIII}_{2}$, siswa yang memperoleh skor antara 0-34 sebanyak 10 siswa atau 29,41\%, 14 siswa atau 41,18\% memperoleh skor pada interval 35-54, 4 siswa atau 11,76\% memperoleh skor pada interval 5564, 5 siswa atau 14,71\% memperoleh skor pada interval 65-84, dan 1 siswa atau 2,94\% yang memperoleh skor pada interval 85-100. Jika skor rata-rata hasil belajar siswa sebesar 45,85 dikonversi ke dalam 5 kategori diatas, maka skor rata-rata hasil belajar matematika siswa kelas $\mathrm{VII}_{5}$ SMP Negeri 18 Makassar setelah diajar dengan menggunakan pendekatan PMR tergolong rendah.

Selanjutnya data hasil belajar setelah pembelajaran metematika realistik dianalisis berdasarkan kriteria ketuntasan sebagai berikut:

Tabel 4.3 Deskripsi Ketuntasan Hasil Belajar Siswa Setelah Penelitian

\begin{tabular}{clcl}
\hline Interval skor & Kategori & Frekuensi & Persentase \\
\hline $0-60$ & Tidak Tuntas & 25 & $73,53 \%$ \\
$61-100$ & Tuntas & 9 & $26,47 \%$ \\
\hline
\end{tabular}

Dari tabel 4.3, siswa yang hasil belajarnya tidak tuntas sebanyak 25 siswa atau $73,53 \%$ sedangkan siswa yang memenuhi kriteria ketuntasan individu sebanyak 18 siswa atau 26,47\% . Jika dikaitkan dengan indikator ketuntasan hasil belajar siswa maka dapat disimpulkan bahwa hasil belajar siswa kelas VII $_{5}$ SMP Negeri 18 Makassar setelah diterapkan pembelajaran matematika realistik pada pokok bahasan persegipanjang dan persegi belum memenuhi indikator ketuntasan hasil belajar siswa secara klasikal.

2. Aktivitas siswa 
Secara garis besar aktifitas siswa kelas VII $_{5}$ SMP Negeri 18 Makassar dapat dikategorikan efektif, hal ini dapat dilihat pada rata-rata persentase aktivitas siswa untuk setiap aspek selama 4 kali pertemuan memenuhi rentang waktu ideal.

3. Respons siswa

Instrumen yang digunakan untuk memperoleh data respons siswa adalah angket respons siswa. Hasil analisis data respons siswa terhadap pelaksanaan pembelajaran matematika realistik yang diisi oleh 34 siswa secara singkat ditunjukkan sebagai berikut:

Tabel 4.4 Data hasil angket respons siswa terhadap pelaksanaan pembelajaran matematika realistik.

\begin{tabular}{|c|c|c|c|c|c|}
\hline \multirow{2}{*}{ No } & \multirow{2}{*}{ Aspek yang Direspon } & \multicolumn{2}{|c|}{$\begin{array}{l}\text { Respons } \\
\text { Siswa }\end{array}$} & \multicolumn{2}{|c|}{ Persentase } \\
\hline & & Ya & Tidak & Ya & Tidak \\
\hline 1 & $\begin{array}{l}\text { Apakah kamu senang dengan } \\
\text { pembelajaran matematika yang } \\
\text { dikaitkan dengan kehidupan } \\
\text { sehari-hari }\end{array}$ & 7 & 7 & $79,41 \%$ & $20,59 \%$ \\
\hline 2 & $\begin{array}{l}\text { Apakah Kamu senang terhadap } \\
\text { masalah yang diberikan oleh guru } \\
\text { di awal pembelajaran? }\end{array}$ & 4 & 10 & $70,59 \%$ & $29,41 \%$ \\
\hline 3 & $\begin{array}{l}\text { Apakah Kamu senang berdiskusi } \\
\text { dengan teman sekelas Kamu } \\
\text { disaat pembelajaran berlangsung? }\end{array}$ & 2 & 2 & $94,12 \%$ & $5,88 \%$ \\
\hline 4 & $\begin{array}{l}\text { Apakah Kamu senang jika guru } \\
\text { memberikan kesempatan bertanya } \\
\text { terhadap masalah yang belum } \\
\text { dipahami? }\end{array}$ & 1 & 3 & $91,18 \%$ & $8,82 \%$ \\
\hline 5 & $\begin{array}{l}\text { Apakah Kamu senang } \\
\text { membandingkan jawaban dengan } \\
\text { jawaban teman sekelasmu? }\end{array}$ & 9 & 5 & $85,29 \%$ & $14,71 \%$ \\
\hline 6 & $\begin{array}{l}\text { Apakah Kamu senang } \\
\text { memberikan kesimpulan terhadap } \\
\text { pembelajaran? }\end{array}$ & 6 & 8 & $76,47 \%$ & $23,53 \%$ \\
\hline 7 & $\begin{array}{l}\text { Apakah Kamu senang dengan } \\
\text { cara guru mengajar? }\end{array}$ & 4 & 0 & $100 \%$ & $0 \%$ \\
\hline 8 & $\begin{array}{l}\text { Apakah Kamu senang dengan } \\
\text { suasana pembelajaran seperti ini? }\end{array}$ & 8 & 6 & $82,35 \%$ & $17,65 \%$ \\
\hline 9 & $\begin{array}{l}\text { Apakah Kamu senang jika } \\
\text { diterapkan cara pembelajaran } \\
\text { seperti ini pada pembelajaran } \\
\text { berikutnya? }\end{array}$ & 5 & 9 & $73,53 \%$ & $26,47 \%$ \\
\hline 10 & $\begin{array}{l}\text { Apakah Kamu senang bertanya } \\
\text { kepada guru? }\end{array}$ & 9 & 5 & $85,29 \%$ & $14,71 \%$ \\
\hline 11 & $\begin{array}{l}\text { Apakah kamu merasakan ada } \\
\text { kemajuan setelah pembelajaran } \\
\text { seperti ini? }\end{array}$ & 33 & 1 & $97,06 \%$ & $2,94 \%$ \\
\hline
\end{tabular}

Berdasarkan tabel 4.4, 79,41\% siswa senang jika pembelajaran dikaitkan dengan kehidupan sehari-hari. 70,59\% siswa senang dengan masalah yang diberikan oleh guru diawal pembelajaran, 94,12\% siswa senang mendiskusikan materi yang belum dipahami dengan teman kelas ketika pembelajaran sedang berlangsung, 91,18\% siswa senang jika diberikan 
kesempatan bertanya kepada guru, 85,29\% siswa senang membandingkan jawaban dengan teman kelompok, $76,47 \%$ siswa senang menyimpulkan hasil pembelajaran, $100 \%$ siswa senang dengan cara mengajar guru, $82,35 \%$ siswa senang dengan suasana pembelajaran matematika realistik, 73,53\% siswa setuju jika pembelajaran matematika realistik diterapkan pada pembelajaran berikutnya, 85,29\% siswa senang bertanya pada guru, 97,06\% siswa merasakan ada kemajuan setelah diterapkan pembelajaran matematika realistik hasil "bersih". Proses analisis data seperti perhitungan statistik dan proses pengujian hipotesis tidak perlu disajikan. Hanya hasil analisis dan hasil pengujian hipotesis saja yang perlu dilaporkan. Tabel dan grafik dapat digunakan untuk memperjelas penyajian hasil penelitian secara verbal. Tabel dan grafik harus diberi komentar atau dibahas.

\section{Simpulan dan Saran}

Berdasarkan hasil penelitian dan pembahasan yang telah dikemukakan sebelumnya maka dapat disimpulkan bahwa:

1. Hasil belajar matematika siswa kelas $\mathrm{VII}_{5}$ SMP Negeri 18 Makassar menunjukkan bahwa 26,47\% siswa mencapai ketuntasan individu. Berdasarkan kriteria ketuntasan hasil belajar dapat disimpulkan bahwa ketuntasan hasil belajar secara klasikal tidak tercapai.

2. Rata-rata persentase setiap kategori aktivitas siswa berada pada rentang waktu ideal. Berdasarkan kriteria aktivitas dapat disimpulkan bahwa aktifitas siswa pada pembelajaran matematika realistik efektif.

3. Pembelajaran matematika realistik pada siswa kelas $\mathrm{VII}_{5}$ SMP Negeri 18 Makassar mendapat respons positif.

4. Berdasarkan kriteria keefektifan pembelajaran maka pendekatan pembelajaran matematika realistik atau PMR materi persegipanjang dan materi persegi tidak efektif diterapkan pada siswa kelas VII SMP Negeri 18 Makassar.

Penelitian ini sangat terbatas sehingga disarankan kepada mahasiswa atau para peneliti di bidang pendidikan khususnya pendidikan matematika untuk melakukan penelitian lebih lanjut guna memperluas hasil-hasil penelitian ini

\section{Referensi}

Agungprudent. 2009. Efektivitas Pembelajaran (Online). Diakses 8 Februari 2018

Diyah. 2007. Kefektivan Pembelajaran Matematika Realistik pada Kemampuan Pemecahan Masalah Siswa Kelas VII SMP. Skripsi. FMIPA Universitas Negeri Semarang.

Hadi, Sutarto. 2008. PMRI, Benih Pembelajaran Matematika yang Bermutu. Diakses 10 Februari 2018

Hadi, Sutarto. 2008. PMR: Menjadikan Pelajaran Matematika lebih Bermakna bagi Siswa. Diakses 10 Februari 2018

Rusdi, Andi. Pengembangan Perangkat Pembelajaran Matematika Realistik Materi Statistika di kelas IX. Diakses pada tanggal 10 Februari 2018.

Yuwono, Ipung. 2007. Pembelajaran Matematika Realistik. Malang: UM Press. 